\title{
The Effect of the World Exchange Indexes (DJIA, SSEC and NIKKEI 225) on the Indonesia Stock Exchange Index (IDX)
}

\author{
Alvin Lesmana ${ }^{1}$ \\ Email: alvin_lesmana@widyadharma.ac.id \\ ${ }^{1}$ Digital Business Study Program Faculty of Technology and Information, Widya Dharma \\ University Pontianak, Indonesia \\ Received: December 5, 2021 \\ Revised: December 28, 2021
}

Accepted: January 9, 2022

\begin{abstract}
This study aims to determine the effect of the Dow Jones Industrial Average (DJIA), Shanghai Stock Exchange Composite (SSEC) and Nikkei 225 Indexes on the movement of the Indonesian Stock Exchange Index (IDX) for the period of November 2016 - November 2021. This study uses non-participant observation methods and the whole population in that time period is used as a sample. Data analysis techniques include descriptive statistics, classical assumption test. The results of the multiple linear regression analysis showed that the DJIA and Nikkei 225 indexes partially had a positive effect on the IDX, while the SSEC Index had no effect on the IDX. However, the value of (R2) shows that only 16.6 percent of the IDX movement can be partially explained by research variables, while 83.4 percent is influenced by factors outside this study.
\end{abstract}

Keywords: IDX, DJIA, SSEC, NIKKEI 225

\section{Introduction}

One of the most popular investment instruments in the world is buying or investing in shares of public listed company. With the development of technology and the rapid flow of information, more and more elements of society are interested and even immediately try to invest their capital in company shares traded in the capital market. The number of investors in Indonesia has increased significantly, this can be seen from the data on the increase in Single Investor Identification (SID). During January - September 2021, the number of SID shares increased by almost 1 million investors, namely, from 2.9 million to 3.88 million stock investors at the end of September 2021 and is expected to continue to increase in line with the increase in financial literacy. The increase in financial literacy is also driven by the rise of influencers who educate, some even show the benefits of their investment in the capital market so that the audience who sees it becomes tempted and even rushes to invest. This is of course very dangerous because even though investment in the capital market aims to increase the value of the assets invested, if it is not carried out with the right analysis and method, it will risk experiencing losses.

With the rapid development in the digital world, there are various platforms that allow investors to invest their money in stock exchanges or cross-border capital markets. So that investment in the capital market between countries becomes very open and the flow of capital does not only come from the domestic capital market but also from across countries. By diversifying a portfolio of mixed stocks on various stock indexes in the world, investors are expected to maximize profits (Nikunj et al, 2012). The movement of the capital market in Indonesia can be seen from the Indonesia Stock Exchange Composite Index (IDX). This index is the weighted average of all stocks listed on the Indonesia Stock Exchange. The rise and fall of the stock price 
index depends on various factors. One of the common factors is allegedly due to the ups and downs of the major stock exchange indexes in the world. For this reason, this study was conducted in order to determine the effect of the world's major stock exchanges on the IDX. Some of the world capital market indexes that are often observed by investors in Indonesia are the Dow Jones Industrial Average (DJIA), the NIKKEI 225 Index, and the Shanghai Composite Index (SSEC). The index represents the stock markets of the United States, Japan and China.

\section{Theoretical Studies}

With the ease of access and encouragement from investors to place their investments in the capital market, stock exchange or stock exchange index across countries, modern portfolio theory has emerged regarding the integration and interdependence of capital markets in various countries. The capital market according to Harjito and Martono (2014: 383) is "a market where long-term funds, both debt and equity, are traded. The long-term funds that are traded are realized in securities."

Indonesia's trade relations with the main export destination countries can certainly have a direct impact on the movement of the Indonesian economy. Based on data from the Ministry of Trade, Indonesia's three largest export destinations are China, America and Japan. The existence of significant economic relations between the three countries causes the Indonesian capital market to be integrated. According to Sakthivel et al. (2012), economic information regarding a country's economic fundamentals will be transmitted to other markets, so that it will affect other stock markets. So that the capital markets of developed countries can affect various capital markets of developing countries including Indonesia.

To record capital market movements, each stock exchange in the world has an index as an indicator and data from daily stock movements that occur in trade every day. The increase in the index value in the capital market indicates an increase in the average value of the shares listed in the index. On the other hand, the decline in the capital market index indicates a decrease in the average value of the shares listed in the index. An increase in the capital market index will be a positive signal and generate optimism for investors, and vice versa if there is a decline in the stock market index it will be a negative sentiment for investors, especially when a sharp decline often causes depression for investors.

Investors often pay attention to market conditions, the macroeconomic conditions of countries that have significant economic relations or are in the same area as the stock exchange where their funds are invested. This is because the conditions of countries in the same region tend to be interrelated. This condition is called the contagion effect, which is an event that spreads economic movements from one country or region to other related countries or regions. In financial markets, capital market relations between countries cause this phenomenon. According to Boubeker and Ngunyen (2019: 150) the contagion effect is defined as a significant cross-market relationship after a shock to a country or group of countries, which is measured by the extent to which the joint movement of assets or financial exchange rates across related markets when conditions are stable. This contagion effect will be more visible in times of crisis, but it does not mean that it does not exist when there is no crisis. The contagion effect can be characterized as the transmission of volatility from one country to another.

According to the same source, namely Boubeker and Ngunyen (2019: 150), the transmission effect occurs due to two main factors. The first factor is capital market interdependence, meaning that a crisis in a country or region can spread to other countries due to financial and economic relations. The second factor is the financial crisis which is not caused by macroeconomic conditions or fundamentals, but is the result of investor behavior. 
The movement of the state capital market will affect each other, especially countries with larger capital flows which will affect the smaller capital market. In this case, the Indonesian capital market as an integral part of the world capital market will be influenced by a larger capital market. Several countries that have great capital power are America, China and Japan, which are sources of foreign capital driving the movement of the domestic capital market.

Capital market movements in the United States are generally represented by three main indexes, namely the Dow Jones Industrial Average (DJIA), also known as the Dow Jones, S\&P 500 and the Nasdaq Composite. In this study, daily movement data from the Dow Jones index will be used as a representative of the movement of the capital market in the United States. The Dow Jones is one of the oldest indices in the world. Created by Charles Dow and his business partner Edward Jones in 1986. The Dow Jones index contains the 30 stocks of the largest and most influential companies on the United States stock exchange.

The United States is the country with the highest Gross Domestic Product (GDP) in the world with an estimated value from the International Monetary Fund (IMF) for 2021 of U\$ 20.49 trillion. In the Asian region, countries with great economic power and influence in the world include China and Japan. Where according to data from the International Monetary Fund (IMF), the country with the largest GDP in Asia and the second in the world is China with an estimated value of US\$13.4 trillion in 2021, while the country with the second GDP value in Asia or the third in the world is Japan with an estimated value of US\$4.97 trillion.

Stock market movements in China are represented by the Shanghai Stock Exchange Composite Index (SSEC) where this index consists of all company shares traded on the Shanghai stock exchange. For Japan, stock market movements are generally seen from the Nikkei 225 index, where this index consists of 225 leading companies on the Tokyo Stock Exchange.

For capital market movements in Indonesia, investors generally pay attention to the IDX, namely the Composite Stock Price Index, where this index consists of all company shares traded on the Indonesia Stock Exchange. The IDX was first introduced in 1983 on the JSE (Jakarta Stock Exchange) before changing its name to BEI or the Indonesia Stock Exchange on November 30, 2007.

Based on the background description, the problems in this research are; (1) Is there any effect of the Dow Jones Industrial Average (DJIA) on the Indonesian Stock Exchange Index ? ; (2) Is there any influence of the Shanghai Stock Exchange Composite Index (SSEC) on the Indonesian Stock Exchange Index?; (3) Is there any effect of the Nikkei 225 Index on the Indonesian Stock Exchange Index?

Previous research (Rahyuda et al., 2014) showed that the follower strategy applied by domestic investors caused the IDX to decline when the DJIA fell during a crisis. Likewise, previous research conducted by Virby (2014) showed that the DJIA had a positive effect on the IDX. Research conducted by Velen (2021) also shows that the DJIA has a positive effect on the IDX.

Research conducted by Virby (2014) concluded that SSEC had a positive effect on the IDX. Likewise, research conducted by Marjohan (2015) shows that SSEC has a positive effect on the IDX movement. Meanwhile, research conducted by Velen (2021) showed that SSEC had no significant effect on the IDX.

Research conducted by Budi, et al in 2013 stated that the effect of the Nikkei 225 index on the IDX was significantly positive. Meanwhile, research conducted by I Wayan Agus Budi Utama, et al. (2015) showed that the Nikkei 225 index had no effect on the IDX. Research conducted by Velen (2021) shows that the Nikkei 225 index has a positive effect on the IDX movement. 
Thus, on the basis of theoretical studies and previous research that has been carried out, the hypotheses proposed in this study are:

H1: The Dow Jones Industrial Average (DJIA) has a positive effect on the Indonesian Stock Exchange Index (IDX).

H2: The Shanghai Stock Exchange Composite Index (SSEC) has a positive effect on the Indonesian Stock Exchange Index (IDX).

H3: The Nikkei 225 index has a positive effect on the Indonesian Stock Exchange Index (IDX)

\section{Methods}

This research was conducted on the Capital Markets of Indonesia, the United States of America, China, and Japan. The dependent variable in this study is the IDX while the independent variables are DJI, FTSE100, Nikkei 225. The data used is quantitative data sourced from www.investing.com. The population in this study is all IDX, DJIA, Nikkei 225 data for the period from November 8, 2016 to November 8, 2021. By adjusting the data, namely equalizing active trading days, so that the data taken is data that contains the same trading day from each exchange that is traded. conducted research. This is done because there are holidays that differ from country to country. Thus the analysis period of this study is 5 years. This time period was taken because 5 years is a fairly long period of time. In addition, in the 2020 period, the COVID-19 pandemic hit several stock exchanges in the world. Thus, the time period above represents some of the capital market turmoil that has occurred in the world. This research can be categorized as a census study which means that the entire population is carried out as a research sample. The analysis technique used is multiple linear regression. Prior to the analysis of multiple linear regression, descriptive statistical analysis was carried out, classical assumption test (normality test, multicollinearity test, heteroscedasticity test, and autocorrelation test). Meanwhile, for multiple linear regression analysis, correlation coefficient test $(\mathrm{R})$, determination ( $\mathrm{R} 2), \mathrm{F}$ test and $\mathrm{t}$ test will be carried out.

\section{Results and Discussion}

\section{Descriptive Statistical Analysis}

Descriptive analysis is done to find out the picture of research data. The results of the statistical analysis can be seen from table 1:

Table 1. Descriptive Statistics

Descriptive Statistics

\begin{tabular}{|l|l|r|r|r|r|}
\hline & N & \multicolumn{1}{|c|}{ Minimum } & \multicolumn{1}{c|}{ Maximum } & \multicolumn{1}{|c|}{ Mean } & \multicolumn{1}{c|}{ Std. Deviation } \\
\hline DJIA & 1051 & 18332,74 & 36431,39 & 26366,6883 & 4244,69166 \\
SSEC & 1051 & 2483,09 & 3715,37 & 3144,8679 & 287,06930 \\
Nikkei 225 index & 1051 & 16251,54 & 30670,10 & 22863,2473 & 3223,32668 \\
Stock Price Index & 1051 & 3937,63 & 6680,62 & 5879,8816 & 499,44757 \\
Valid N (listwise) & 1051 & & & & \\
\hline
\end{tabular}

Source: Processed Data 2021

From Table 1, it can be seen that in the period from November 8, 2016 to November 8, 2021 (5 years) what are the highest, lowest and average values of each index. DJIA touched a high of 36431.39 points and a low of 18332.74 points. The SSEC index touched a high of 3715.37 and a low of 2483.09. The Nikkei 225 index touched a high of 30670.10 and a low of 16251.54. Meanwhile, the IDX during this period touched the highest value at 6680.62 and the lowest at 3937.63. 


\section{Classic Assumption Test}

Classical assumption tests include tests of normality, heteroscedasticity, multicollinearity, and autocorrelation in the regression model. The results of processing the classical assumption test data are summarized in the following tables:

Table 2. Normality Test

One-Sample Kolmogorov-Smirnov Test

\begin{tabular}{|ll|l|}
\hline & & $\begin{array}{l}\text { Unstandardized } \\
\text { Residual }\end{array}$ \\
\hline $\mathrm{N}$ & & 1051 \\
Normal & Mean &,- 0024484 \\
Parameters & Std. &, 14922784 \\
& Deviation & \\
Most Extreme & Absolute &, 038 \\
Differences & Positive &, 038 \\
Kolmogorov-Smirnov Z & Negative &,- 036 \\
\multicolumn{2}{|l|}{ Asymp. Sig. (2-tailed) } & 1,221 \\
\hline
\end{tabular}

a. Test distribution is Normal.

b. Calculated from data.

Source: Processed Data, 2021

Table 3. Heteroskedasticity Test

\section{Coefficients $^{\mathbf{a}}$}

\begin{tabular}{|c|c|c|c|c|c|c|}
\hline \multirow{2}{*}{\multicolumn{2}{|c|}{ Model }} & \multicolumn{2}{|c|}{$\begin{array}{l}\text { Unstandardized } \\
\text { Coefficients }\end{array}$} & $\begin{array}{l}\text { Standardized } \\
\text { Coefficients }\end{array}$ & \multirow[t]{2}{*}{$\mathrm{t}$} & \multirow[t]{2}{*}{ Sig. } \\
\hline & & $\mathrm{B}$ & Std. Error & Beta & & \\
\hline \multirow{4}{*}{1} & (Constant) & 3,233 &, 427 & & 7,575 & ,000 \\
\hline & DJIA &,- 124 & ,083 &,- 126 & $-1,496$ & 135 \\
\hline & SSEC &,- 001 &, 064 &,- 001 &,- 016 & ,987 \\
\hline & Nikkei 225 index &,- 182 & 104 &,- 162 & $-1,743$ & ,082 \\
\hline
\end{tabular}

a. Dependent Variable: ABS_RES

Source: Processed Data, 2021

Table 4. Multicollinearity Test

\section{Coefficients $^{\mathrm{a}}$}

\begin{tabular}{|l|l|l|l|l|l|l|l|}
\hline Model & \multicolumn{2}{|l|}{$\begin{array}{l}\text { Unstandardized } \\
\text { Coefficients }\end{array}$} & $\begin{array}{l}\text { Standardized } \\
\text { Coefficients }\end{array}$ & $\mathrm{t}$ & \multicolumn{2}{l|}{ Itself. } & \multicolumn{2}{l|}{$\begin{array}{l}\text { Collinearity } \\
\text { Statistics }\end{array}$} \\
\cline { 2 - 4 } \cline { 6 - 9 } & $\mathrm{B}$ & $\begin{array}{l}\text { Std. } \\
\text { Error }\end{array}$ & Beta & & & $\begin{array}{l}\text { Tolera } \\
\text { nce }\end{array}$ & $\begin{array}{l}\text { BRI } \\
\text { GHT }\end{array}$ \\
\hline (Constant) & 3,842 &, 392 & & 9,792 &, 000 & & \\
DJIA &, 153 &, 076 &, 162 & 2,011 &, 045 &, 123 & 8,126 \\
SSEC &, 108 &, 059 &, 067 & 1,840 &, 066 &, 601 & 1,663 \\
Nikkei 225 index &, 237 &, 096 &, 219 & 2,469 &, 014 &, 101 & 9,860 \\
\hline
\end{tabular}

a. Dependent Variable: Stock Price Index

Source: Processed Data, 2021

Copyright (O 2022, Journal of Asian Multicultural Research for Economy and Management Study,

Under the license CC BY-SA 4.0 
Table 5. Autocorrelation Test

Model Summaryb

\begin{tabular}{|l|l|l|l|l|l|}
\hline $\begin{array}{l}\text { Mo } \\
\text { del }\end{array}$ & $\mathrm{R}$ & $\begin{array}{l}\mathrm{R} \\
\text { Square }\end{array}$ & $\begin{array}{l}\text { Adjusted R } \\
\text { Square }\end{array}$ & $\begin{array}{l}\text { Std. Error } \\
\text { of the } \\
\text { Estimate }\end{array}$ & $\begin{array}{l}\text { Durbin- } \\
\text { Watson }\end{array}$ \\
\hline 1 &, $410^{\mathrm{a}}$ &, 168 &, 166 &, 13693 & 1,932 \\
\hline
\end{tabular}

a. Predictors: (Constant), Indeks Nikkei 225, SSEC, DJIA

b. Dependent Variable: Stock Price Index

Source: Processed Data, 2021

From the processed data, it can be seen from Table 2 that the asymp.sig value is $0.101>0.05$ so it can be concluded that the data is normally distributed. Table 3 shows that the probability value is greater than 5\% (0.05), thus the variables proposed in the study do not occur heteroscedasticity. Table 4 shows that the tolerance value $>0.10$ or VIF value $<10$, then there is no multicollinearity. Table 5 shows that there is no autocorrelation, it is said that there is no autocorrelation if DU<DW <4-DU. From table 5, it can be seen that the value of DU $=1.90454$, $\mathrm{DW}=1.932$, $4-\mathrm{DU}=2.09546$ so that $1.90454<1.932<2.09546$ concluded that there was no autocorrelation.

\section{Influence Analysis}

Based on the results of data processing, results are obtained as in the following table:

Table 6. Model Summary

\begin{tabular}{|l|l|l|l|l|}
\hline $\begin{array}{l}\text { Mo } \\
\text { del }\end{array}$ & $\mathrm{R}$ & $\begin{array}{l}\mathrm{R} \\
\text { Square }\end{array}$ & $\begin{array}{l}\text { Adjusted R } \\
\text { Square }\end{array}$ & $\begin{array}{l}\text { Std. Error } \\
\text { of the } \\
\text { Estimate }\end{array}$ \\
\hline 1 &, $410^{\mathrm{a}}$ &, 168 &, 166 &, 13693 \\
\hline
\end{tabular}

a. Predictors: (Constant), Nikkei Index 225, SSEC, DJIA

Source: Processed Data, 2021

Table 7. Anova ${ }^{\mathrm{a}}$

\begin{tabular}{|ll|l|l|l|l|l|}
\hline \multicolumn{2}{|l|}{ Model } & $\begin{array}{l}\text { Sum of } \\
\text { Squares }\end{array}$ & df & $\begin{array}{l}\text { Mean } \\
\text { Square }\end{array}$ & F & Sig. \\
\hline \multirow{2}{*}{1} & Regression & 3,964 & 3 & 1,321 & 70,477 &, $000^{\mathrm{b}}$ \\
& Residual & 19,632 & 1047 &, 019 & & \\
& Total & 23,596 & 1050 & & & \\
\hline
\end{tabular}

a. Dependent Variable: Stock Price Index

b. Predictors: (Constant), Nikkei Index 225, SSEC, DJIA

Source: Processed Data, 2021

Table 8. Coefficients ${ }^{\mathrm{a}}$

\begin{tabular}{|c|c|c|c|c|c|c|}
\hline \multirow{2}{*}{\multicolumn{2}{|c|}{ Model }} & \multicolumn{2}{|c|}{$\begin{array}{l}\text { Unstandardized } \\
\text { Coefficients }\end{array}$} & $\begin{array}{l}\text { Standardized } \\
\text { Coefficients }\end{array}$ & \multirow[t]{2}{*}{$\mathrm{t}$} & \multirow[t]{2}{*}{ Sig. } \\
\hline & & $\mathrm{B}$ & Std. Error & Beta & & \\
\hline \multirow{4}{*}{1} & (Constant) & 3,842 & ,392 & & 9,792 & ,000 \\
\hline & DJIA &, 153 & ,076 & , 162 & 2,011 &, 045 \\
\hline & SSEC & 108 & (059, & ,067 & 1,840 & , 066 \\
\hline & Nikkei Index 225 & ,237 & ,096 & ,219 & 2,469 & ,014 \\
\hline
\end{tabular}

Copyright $\odot$ 2022, Journal of Asian Multicultural Research for Economy and Management Study, Under the license CC BY-SA 4.0 
a. Dependent Variable: Stock Price Index

Source: Processed Data, 2021

\section{Multiple Liner Regression Analysis}

Multiple linear regression analysis was used to measure the effect of more than one independent variable (independent) on the dependent variable. Multiple linear regression analysis is a linear relationship between two or more independent variables $(\mathrm{X} 1, \mathrm{X} 2, \ldots \mathrm{Xn})$ with the dependent variable $(\mathrm{Y})$. This analysis is to determine the direction of the relationship between the independent variable and the dependent variable whether each independent variable is positively or negatively related.

Based on the results of data processing shown in table 8 , the multiple linear regression equation formed is as follows:

$$
\mathrm{Y}=3,832+0,153 \mathrm{X}_{1}+0,108 \mathrm{X}_{2}+0,237 \mathrm{X}_{3}+\varepsilon
$$

From the regression model above, it can be explained as follows:

The constant showing the number 3,842 means that mathematically the IDX Index during the 2016-2021 observation period is at the level of 3,842. If the DJIA, SSEC and NIKKEI 225 indexes are at the zero level. B1 of 0.153 means that if the DJIA Index increases by 1 point, it will cause an increase in the IDX Index of 0.153 points. B2 of 0.108 means that if the SSEC Index increases by 1 point, it will cause an increase in the IDX Index of 0.108 points. B3 of 0.237 means that if the NIKKEI 225 Index increases by 1 point, it will cause an increase in the IDX Index of 0.237 points.

\section{Correlation Coefficient \& Determination}

The results of data processing shown in Table 6 show a correlation coefficient (R) of 0.410 which indicates a relationship between the independent variable and the dependent variable. The value of the coefficient of determination $\left(\mathrm{R}^{2}\right)$ is 0.166 or 16.6 percent. This shows that the effect of the DJIA Index, SSEC, NIKKEI 225 on the IDX is only 16.6 percent while the 83.4 percent increase or decrease in the IDX is influenced by factors outside this study.

\section{Test F}

Based on the data that can be seen in Table 7. From the results of the F test in the table above, it is obtained that the calculated $\mathrm{F}$ is 70.477 and the probability is 0.000 . Because sig Fcount $<5 \%(0.000<0.05)$, it can be concluded that the Nikkei 225 Index, SSEC, DJIA jointly affect the Stock Price Index.

\section{Test t}

From the data processing results shown by Table 8 . The results of the $t$ test are as follows; (1) Based on the results of the partial regression test for the DJIA Index, the t-count value is 2.011, the regression coefficient (beta) is 0.153 with probability $(p)=0.045$. Based on the results of data processing where the probability value (p) 0.05 , it can be concluded that the DJIA has a positive and significant effect on the IDX index so that Hypothesis 1 is accepted; (2) Based on the partial regression test of the SSEC Index, the t-count value is 1,840, the regression coefficient (beta) is 0.108 with probability $(\mathrm{p})=0.066$. Based on the results of data processing where the probability value (p) 0.05 , it can be concluded that the SSEC Index is not significant to the IDX, so Hypothesis 2 is rejected.

Based on the partial regression test of the NIKKEI 225 index, the t-count value is 2.469 regression coefficient (beta) 0.237 with probability $(p)=0.014$. Based on the results of data 
processing where the probability value (p) 0.05 , it can be concluded that the NIKKEI 225 index has a positive and significant effect on the IDX, so Hypothesis 3 is accepted

\section{Conclusion}

The conclusion that can be drawn from the results of this study is partially, the Dow Jones Index (DJIA) and NIKKEI 225 Index variables have a positive effect on the Indonesian stock index represented by the IDX. While the Shanghai Stock Exchange Composite Index (SSEC) has no effect on the IDX. Although the DJIA Index and NIKKEI 225 have a positive effect on the IDX, it should be noted that the value of R2 is 0.166 , which means that the variables of this study, namely the DJIA Index, SSEC and NIKKEI 225 only have an effect of 16.6 percent on the IDX, while 83.4 percent is influenced by models outside of research. Thus, it can be concluded that the dependence of domestic investors on changes in major indices abroad is decreasing, unlike what was concluded from previous studies which obtained R2 results above 50 percent. It is recommended for stock investors to observe and learn more about what factors affect the index or stock price of a company so that the risk of loss can be avoided and in the end can reap the benefits of investing in the stock market. For further research, it is advisable to look at other factors such as domestic political and economic policies that may influence the movement of the IDX. In addition, differences in regulations such as the Lower Auto Rejection limit of 7 percent and the Upper Auto Rejection limit that adjusts to price fractions can also affect IDX fluctuations.

\section{References}

Anwar, S. (2011). Metode Penelitian Bisnis. Jakarta: Salemba Empat.

Boubaker, Sabri, \& Duc Khuong Nguyen. (2019). Handbook of global financial markets :

Budi, S., Werner R. M., dan Endang, E. 2013. Analisis pengaruh ekonomi makro, Indeks Dow Jones dan Nikkei 225 terhadap Indeks Harga Saham Gabungan (IDX) di BEI periode 2007-2011. Calyptra: Jurnal Ilmiah Mahasiswa Universitas Surabaya, 2 (1)

Harjito, D. Agus, dan Martono. (2014). Manajemen Keuangan Edisi ke 2. Yogyakarta: Ekonisia.

Marjohan, Masno. (2015). Effect of Stock Price Index in Global Stock against Composite Stock Price Index (IDX) Study on Indonesia Stock Exchange. Journal of Economics and Finance, vol.6, pp. 15-23.

Nikunj, R. P., Sushil, M., and Neeta, P. (2012). Are stock markets interdependent? A study on selected stock markets. Asian Journal of Research in Business Economics and Management, 2 (11)

Priyatno, Duwi. (2016). SPSS Handbook: Analisis Data, Olah Data, \& Penyelesaian KasusKasus Statistik. Yogyakarta: MediaKom. Publishing.

Rahyuda, H., Purbawangsa, I. B. A., \& Andiyasa, I. G. A. (2014). Pengaruh Beberapa Indeks Saham dan Indikator Ekonomi Global terhadap Kondisi Pasar Modal Indonesia. EJurnal Ekonomi dan Bisnis Universitas Udayana, 44686.

Riduwan. (2016). Pengantar Statistika Sosial. Bandung: Alfabeta.

Utama, I Wayan A. B \& Artini, Luh G. S. (2015). Pengaruh indeks bursa dunia pada harga saham gabungan bursa efek Indonesia. Jurnal Manajemen, Strategi Bisnis dan Kewirausahaan Vol.9, No. 1.

Velen. (2021). Analisis pengaruh indeks Dow Jones Industrial Average (DJIA), Indeks NIKKEI 225, dan Indeks Shanghai Composite (SSEC) terhadap indeks Harga Saham

Copyright $@$ 2022, Journal of Asian Multicultural Research for Economy and Management Study,

Under the license CC BY-SA 4.0 
Gabungan (IDX). Skripsi Sarjana Program Studi Manajemen Fakultas Ekonomi dan Bisnis Universitas Widya Dharma Pontianak.

Virby, S. (2017). Pengaruh Indeks Dow Jones Industrial Average, Nikkei 225, Hangseng Index, dan Shanghai Stock Exchange terhadap Indeks Harga Saham Gabungan Bursa Efek Indonesia Periode Tahun 2008-2013. Inovasi, 4(2). 